\title{
EPIDEMICS CAUSED BY CONTAMINATION OF DRINKING WATER SUPPLIED BY PUBLIC WATER SUPPLY SYSTEMS IN TERMS OF CURRENT LEGISLATION
}

\author{
Vít Vlček \\ Central Institute for Supervising and Testing in Agriculture, Brno, Czech Republic
}

\section{SUMMARY}

Objectives: This paper describes and comments on contemporary legislation concerning prevention of epidemics caused by contaminated drinking water from public water supplies in the Czech Republic.

Methods: Suggestions are made for removing existing legislative shortcomings, clarifying diction of existing laws and expanding sanctions and penalties for health injury caused by providers and operators of public drinking water.

Results: The author reflects on improving legislation concerning the compensation of victims of contaminated water with reference to the aftermath of a local epidemic in the Dejvice District of Prague.

Conclusion: The issues raised should be addressed since better legislation can significantly contribute to the limitation of water-borne epidemics and their consequences.

Key words: public water supply system, water supply operator, drinking water, legal causes of systemic shortcomings, epidemic

Address for correspondence: V. Vlček, Pod Kaštany 245/10, 16000 Prague 6, Czech Republic. E-mail: vitvlcek@seznam.cz

https://doi.org/10.21101/cejph.a5093

\section{INTRODUCTION}

This text deals with outbreaks of diseases caused by drinking water from the mains from the point of view of prevention and limiting consequences namely on the ground of contemporary legislation of the Czech Republic (1).

Some recent events, for example the outbreak in Dejvice, a quarter of Prague, have shown that in connection with breakdowns, modifications, repairs, and maintenance of water mains, besides other inconveniences, outbreaks of contagious diseases could occur. Among other instruments for the prevention of these extraordinary events is very important a brief, exact, definite, transparent, and effectively enforceable legal regulation, which would also fully implement regulations of European law.

First of all, it should be emphasized that the right of protection of life and health is a natural right, in the Czech Republic constitutionally guaranteed by Article 31 of the Constitutional Charter of Fundamental Rights and Freedoms 2/1993 Coll. In accordance with constitutional protection, the right to protection of life and health is enshrined in the Civil Code 89/2012 Coll.

The legal order should serve as an aid instrument for responding promptly to outbreaks and mitigating the consequences of outbreaks. Private law regulation mainly refers to citizens and primarily serves to compensate for injuries. However, private law also participates in the regulation of operators' obligations.

Public-law regulation imposes a majority of operational obligations on operators and owners of water mains and provides for penalties for their breach.
Public-law penalties for breach of obligations along with private-law compensation should act educationally to possible tortfeasors to prevent outbreaks.

This work attempts to describe the influence of law on the given issue, taking into account the above-mentioned facts.

\section{Private Law Regulation}

The Czech Civil Code contains the legal definition of private law, i.e. a summary of all provisions of the legal order governing the mutual rights and obligations of persons (2). The application of private law is then independent of the application of public law.

Private-law relationships characterize the symmetry and equality of their participants.

As regards the harm and the associated damage, the harm expressible in monetary terms and liability arises therefrom, to draw such liability is a very important conclusion allowing both educative and reparative function. Without acceptable pecuniary compensation for health damage and personal suffering, the educational and moral effect cannot be achieved. The liability of a water supply operator for harm and damage is given, unless the operator proves that all care that can be reasonably required in order to prevent damage has been taken.

\section{Public Law Regulation}

The characteristic feature of public law is that the legal relations modified are asymmetrical and unequal (hierarchical), cor- 
responding to the relationship between the state and citizen (2). It is the legal superiority of the public authorities, which can decide on the subjective rights of other individuals and legal entities, but only within the framework of the law.

In order to prove negligence, it will be usually necessary to prove that all measures that can be reasonably requested to prevent the damage or another harmful consequence were not exercised.

Herein are considered criminal consequences in the event of contamination of drinking water and disability in populations. The assumption of criminal (tort) liability is proven negligence. The care that can be reasonably requested in connection with the operation of public water supply is defined only in general terms.

The definition shall be compiled from more acts on water and sewerage as well as on public health. It depends on the court or administrative body how they create definitions of care in order to punish the tortfeasor for not doing so. Therefore, judicial or administrative discretion can be very wide, so negligence of particular person will be in many cases difficult to prove $(3,4)$. Because we can always expect more victims, the penal responsibility should take into account the negligent public menace according to Criminal Code 40/2009 Coll. The criminal liability of legal persons may be inferred under Act on Criminal Liability of Legal Persons and Procedure against Them 418/2011 Coll. Criminal liability can be attributed to the legal person, so the senior employees also assume negligence comparable to negligent public menace. Therefore, there is no significant difference in proving the criminal liability of persons or legal entities.

The Act on Water Supply and Sewerage 274/2001 Coll is the main source of public law related to the operation of public water mains. This Act regulates the rights and obligations of the operator of water supply mains. This regulation is rather vague (5), including the mentioned contract providing for cooperation (rights and obligations) between the owner and operator of water supply as well as for cooperation among the owners of water supplies operationally related. Therefore, this legal norm is, in terms of the operator's obligations and of health risk prevention, truly inconclusive and mixing the public-law duties with private obligations.

According to this Act (5), the obligation to report to public health authorities is set only when the supply of drinking water is interrupted or restricted. It may be too late. In general, the public health authority will not restore water supplies. Thus, for example, an immediate report to the public health authority on any suspicion of contamination should be more important. The procedure is regulated by Act 258/2000 Coll. on Protection of Public Health. However, there is the first and foremost obligation imposed on operators of public water supplies and other persons supplying potable water listed (2) to take corrective action and only then to inform the public health authority. It seems more appropriate to inform the competent authority before taking corrective action so that the whole procedure is already monitored by the authority and can be checked upon.

The Federal Republic of Germany (FRG) can be named for comparison. The FRG has directly stated in an Act that drinking "water is to be produced according to generally accepted technical rules". It is a set of technical standards and methodical recommendations of the German Association of Gas and Water Suppliers and the Federal Environmental Agency. When an operator of water supply mains is not proceeding according to these standards and recommendations, the operator has to prove to the public health authority that the method used is at least as good or as safe as the method which complies with standards. Otherwise the operator is responsible for violating the law. Good manufacturing practice thus actually becomes binding.

The Act on Protection of Public Health 258/2000 Coll. is the main source of law governing the supply of quality drinking water and the control of its quality. The Act defines the term "drinking water" and lists the basic obligations of operators of public water supplies and providers of drinking water for public use (6-9).

\section{Current Situation in the Czech Republic and the European Union}

Outbreaks caused by contaminated drinking water are recorded in the Czech Republic. Five-year reports have been published since 1995. Not all causes of epidemic outbreaks, however, can be identified. The majority of society does not perceive the safety of drinking water as a problem to which attention should be paid (10). Dozens of small water suppliers still exist and are granted an exception, in terms of water quality, which does not match the hygiene requirements (11).

The following problems result from the whole issue:

- Proving responsibility, namely criminal liability or objective responsibility for delicts;

- Checking of water quality and conditions for water safety by water administration;

- Concrete and intelligible, properly legally established procedure for emergencies and investigation of accidents and incidents;

- Legally established procedure concerning public water supply systems for construction works, repairs, procedures after repairs, maintenance, and operation in general (e.g. mandatory flushing) and their scope;

- Informing the public, its timeliness and scope;

- Compensation for injuries and damages;

- Effectiveness of sanctions;

- Effectiveness of preventive action by administrative authorities.

Proving responsibility, namely criminal liability or objective responsibility for delicts

For culpability in the context of criminal liability is necessary to prove negligent failure to fulfil obligations which consequence is the supply of contaminated drinking water to customers. Sometimes difficulties can be expected, e.g., in case of tightness breakage and impermeability pipeline system resulting in contamination of drinking water it can be very difficult to prove who caused the breakage, whether a person or a force majeure, who checked the pipeline, whether there is any duty to inspect pipelines, when the leak occurred, etc. (12). As for strict liability for delicts, person is not responsible for a delict if he/she proves that every effort required has been undertook. So, any delict may be difficult to prove due to these legal exculpations.

Checking of water quality and conditions for water safety by water administration (13)

An operator of water supply is obliged to take samples of raw water at sampling point before its treatment and conduct analyses, and then to send results in electronic form to the regional office. 
Technical audit may also contribute to the water quality control. Technical audit is a specialized professional activity serving, among other things, to control the technical state of water supply and sewerage. In contrast to the supervision exercised by the state and municipal authorities, the technical audit is carried out by private individuals to which the state authorities transfer their competence.

The legal rules are not conducive to engagement of the water authority in matters of appropriate quality and safety of drinking water. The role of water authorities is not established by Act No. 258/2000 Coll., on Protection of Public Health. The operator reports to the public health body only certain facts, namely the announcement of an interruption or reduction of water supply, or announcement of impaired water quality. The obligation and responsibility for drinking water quality (9) is imposed on the operator of water supply for public needs and other persons in a similar position: owner of the water supply for public needs, who holds the rights and obligations of the operator, person who provides alternative drinking water supply, person who produces drinking water from an individual source as part of business using drinking water, and person who supplies drinking water for public use.

The Decree of the Ministry of Health, laying down hygienic requirements for drinking and hot water and the frequency and extent of drinking water control, specifies the mandatory scope and frequency of drinking water control and the transmission of results to public health authorities through an electronic system called PIVO.

Legislation in general, due to its incomplete precision and thus incomplete comprehensibility, does not contribute enough to reduce potential health risks posed by exposure of people to risk factors.

Legislation does not contribute in a clear and comprehensible way to reducing the incidence of health risks to reasonably achievable exposure.

Concrete and intelligible, properly legally established procedure for emergencies and investigation of accidents and incidents

The matter is regulated only in general by Constitutional Act 110/1998 Coll. on Security of the Czech Republic and Act 240/2002 Coll. Crisis Act. There is no specific emergency legislation on drinking water.

Legally established procedure concerning public water supply systems for construction works, repairs, procedures after repairs, maintenance, and operation in general (e.g. mandatory flushing) and their scope

Good Operational Practice should follow the amendment to Act on Protection of Public Health (by Act 202/2017 Coll.). This legislation should establish rules under which the operator of public water supply system will avoid risks rather than respond to the risks, as was the case of the previous regulation. A full evaluation of the current legislation effectiveness will come from practice.

\section{Informing the public, its timeliness and scope}

Informing the public in case of crisis is ensured (Act on Protection of Public Health 258/2000 Coll). Timeliness should be emphasized. Fines imposed for a breach of duty may reach up to $500,000 \mathrm{CZK}$.

\section{Compensation for injuries and damages}

There should be a strict liability $(14,15)$. Strict liability can be inferred from e.g. the Civil Code (CC), section Damage resulting from operating activities. There is an exemption: if the tortfeasor proves that he/she has exercised all care that can be reasonably requested to prevent the damage. In this context we should also consider the provision of CC on damage caused by a particularly hazardous operation, when "the damage was externally caused by force majeure or by the very acts of the victim or unavoidable acts of a third person". In terms of definition: “An operation is particularly hazardous if the possibility of serious damage cannot be reasonably excluded in advance even by exercising due care." a coincidental damage of sewer and water mains cannot be excluded with respect to the effects of natural forces, e.g. heavy rainfall, geological phenomena, etc. (16).

Regarding monetary compensation of injury to health, there is an important regulation defined in CC. The Civil Code also provides a legal framework for providing compensation to the victim in case of bodily harm for such harm in money, fully compensating for the pain and other non-pecuniary harm suffered and also for deteriorated social position of the victim. It is a debate whether the aforementioned claims are separate claims or whether they are parts of the same claim. There is a predominant view, that these are separate claims. It may be important in particular cases in terms of the procedural position of the victim and it can affect the time limits. This is a matter that should be de lege ferenda clarified. Regarding a compensation $(14,15,17)$, Decree 440/2001 Coll. on compensation for pain and the aggravation of social position has been repealed because the rules contained in the decree impermissibly limited the courts in possibility to admit fair and adequate compensation namely for severe permanent disability. However, a new legislation is entirely focused on judicial proceedings. The repealed Decree provided solutions in some cases for indisputable compensations, and compensations out of court. Scoring system of permanent consequences using medical opinion established a basis for calculating the compensation. There is currently no tool to help indisputably evaluate the damage. Under current legislation, courts do not have a legislative framework for decision-making. Currently there is a non-binding methodology of the Supreme Court to compensate the pain and non-pecuniary harm suffered. The methodology is essentially given only in case of injuries. However, it should also cover diseases or poisonings and changes in health status of the victims due to diseases or poisonings caused by contaminated water. Nowadays, the methodology is difficult to apply during water accidents.

\section{Effectiveness of sanctions}

The effectiveness of sanctions is sufficient but can be problematic in the current indemnity whereas the overall commitment of the tortfeasor may be too high in terms of the financial penalty and monetary compensation.

\section{Effectiveness of preventive action by administrative authorities}

The legal regulation actually does not establish the competence of water authorities to control and enforce the safe operation of public water supply network and drinking water quality. Act 274/2011 Coll. on Water Supply and Sewerage Systems in terms of supervision of drinking water quality refers to Act 258/2000 Coll. on Protection of Public Health, and this Act also implies the 
competence of public health authorities. Water authorities often rely on the safe operation of public water supply systems and do not actually make any control of operation and conditions of the infrastructure. Changes to legislation in which the supervisory duties of the water authorities will be extended and refined appear to be necessary.

\section{RESULTS}

The necessary improvements to the legislation mainly concern the Act on Water Supplies and Sewerage 274/2001 Coll., so the following measures are recommended:

To define precisely the rights and obligations of water supply operators and objectively determine the liability for breach of obligations thus laid down in Act on Water Supplies and Sewerage 274/2001 Coll. (18).

To determine the duties as described above with respect to both small water supply systems and large water supply systems and to take into account the minor's own staff expertise in small water supply systems.

To establish basic procedures for preparing water mains construction, repair of water supply, and treatment of water supply. Exact procedures and obligations are missing.

To determine more precisely water quality control in the abovementioned activities.

To render more precise rules for monitoring of water supply for public needs on both sides, i.e. operators and water authorities (19).

To eliminate legislative shortcomings, namely, to implement legislation to unify dual interpretations. To ensure competence of building authorities for the management of water supply construction and water mains connections, and ensure competence of authorities for protection of public health within Act on Water Supply and Sewerage (20). Generally, to separate public law regulations from private law regulations.

To toughen penalties for substantial negligence or intent in connection with the above-mentioned precision of rights and obligations.

To emphasize the role of bodies for protection of public health.

To increase control activities of water authorities with the duty to inform the bodies for protection of public health.

To oblige health-care facilities, water authorities and all relevant authorities with the duty to provide information on epidemics caused by contaminated water from a public water supply and maintain a national register of such epidemics, probably through the Chief Public Health Officer (258/2000 Coll. on Protection of Public Health)

To consider vaccinations and any other preventive health measures binding, including participation of health insurance companies (Act on Protection of Public Health and Act 48/1997 Coll. on Public Health Insurance). There are a number of possible questions about vaccination. From the legal point of view, compulsory vaccinations are important. In case of vaccination imposed by law, the question of liability for personal injury caused by such vaccination can be mentioned. In the Czech Republic, the legislation places a burden of liability on the healthcare facility that carries out the vaccination. The relevant new act is still under preparation. On the other hand, in Germany, for example, the state is responsible as the compulsory vaccination is carried out as a duty imposed by the state. Although in the Czech Republic there is also a duty imposed by the state, the state does not bear liability for damages caused by the fulfilment of this duty (21).

To consider specifying further compensation for victims (89/2012 Coll., new Czech Civil Code).

To further specify obligatory procedures in crisis situations.

The whole issue can be summed up so that is needed: to give precision to operation of water supplies, to make binding good operational practice, to extend control practice of water authorities, e. g. to improve order in the matter of protective zones, to create better conditions for fair compensation for non-material injury to health in the above-mentioned outbreaks.

\section{DISCUSSION}

The contemporary situation cannot be regarded as satisfactory when in a large-scale epidemic in Prague's district Dejvice in 2015 the tortfeasor solved compensation claims by providing a compensation of 5,000 CZK to those who proved the injury by submitting documentation from a medical practitioner. While many of the victims were subjected to agonizing consequences for several weeks, the first problem was to prove harm to their health when the patient was unable to leave home for health reasons, and general practitioners usually do not exercise visits. When the patient recovers, the problem occurs in proving the harm suffered. Expectations are uncertain about the amount of compensation in case of litigation. Most of the victims thus resign to the enforcement of their claims in court proceedings. This situation allows a tortfeasor to get rid of his responsibility more easily and cheaply than it would correspond to the nature of injury for the majority of victims. Therefore, this situation does not sufficiently motivate a tortfeasor to prevent incidents in drinking water supplies, although outbreaks are often associated with severe diarrhoea and other digestive problems which may have fatal consequences. Relevant criminal responsibility should be refined and slightly tightened.

From a legislative perspective to the future: any interference with the jurisdiction of administrative bodies can be a politically sensitive issue. It is also likely that the authors of the draft legislation will not want to recognize the existing legislative shortcomings in these regulations because they would have to acknowledge their mistakes. Even in good will it would be a demanding task, e.g. Act on Water Supply and Sewerage, in which there is a mixture of unacceptable private and public law regulations, which creates collision with the wording of the new Czech Civil Code and so leads to complicated and contradictory legal practice. This leads to legal uncertainty, unpredictability and surprising effects of the decisions of administrative bodies. Of course, the above-mentioned legislative shortcomings may also impede the proper exercise of judicial power.

\section{CONCLUSION}

The issues raised should be addressed since good legislation can significantly contribute to reductions of epidemic outbreaks 
caused by contaminated drinking water from water supplies for public needs and mitigating the extent of their consequences.

\section{Acknowledgements}

Author would like to thank MUDr. P. Chýle, CSc. and Mr. Radek Choděra for language consultations and MUDr. F. Kožíšek, CSc. for communicating inspiring expert opinions on the issue. Author also would like to thank JUDr. Petr Šustek, Ph.D. for giving helpful comments.

\section{REFERENCES}

1. Svoboda P, Ondřejek P, Šustek P, Hlaváček K, Povolná M, Šturma P. Philosophical and legal theoretical aspects of human rights. Prague: Charles University, Faculty of Law; 2013. (In Czech.)

2. Gerloch A. Theory of law. Dobrá Voda: Aleš Čeněk; 2000. (In Czech.)

3. Jemelka L, Pondělíčková K, Bohadlo D. Code of administrative procedure: commentary. 2nd ed. Prague: C.H. Beck; 2009. (In Czech.)

4. Vedral J. Code of administrative procedure: commentary. 2nd ed. Prague: Bova Polygon; 2012. (In Czech.)

5. Rubeš P. The Act on water supplies and sewerage: commentary. Prague: Wolters Kluwer; 2014. (In Czech.)

6. Sharma S, Bhattacharya A. Drinking water contamination and treatment techniques. Appl Water Sci. 2017 Jun;7(3):1043-67.

7. Fawell J, Nieuwenhuijsen MJ. Contaminants in drinking water. Br Med Bull. 2003;68:199-208

8. Tuček M, et al. Hygiene and epidemiology. Prague: Karolinum; 2012. (In Czech.)

9. Krýsa I, Krýsová Z. The Act on protection of public health: commentary. Prague: Wolters Kluwer; 2016. (In Czech.)
10. Hunter PR, MacDonald AM, Carter RC. Water supply and health. PLoS Med. 2010 Nov 9;7(11):e1000361. doi: 10.1371/journal.pmed.1000361.

11. Kožíšek F, Paul J, Datel JV. Ensuring the quality of drinking water in small water supply systems. Prague: T. G. Masaryk Water Research Institute; 2013. (In Czech.)

12. Jemelka L, Vetešník P, Libosvár O. Control act (control code): commentary. Prague: C.H. Beck; 2014. (In Czech.)

13. Oram B. Why fecal coliform testing is important - e. coli? Dallas: Water Research Watershed Center; 2014.

14. Švestka J, Dvořák J, Fiala J, et al. Commentary on the new civil code. Prague: Wolters Kluwer; 2014. (In Czech.)

15. Eliáš K, et al. New civil code with updated explanatory report and index. Ostrava: Sagit; 2012. (In Czech.)

16. Svejkovský J, et al. New civil code: comparison of new and contemporary regulation of civil law. Prague: C.H. Beck; 2012. (In Czech.)

17. Bureš J, Drápal L, Krčmáŕ Z, et al. Code of civil procedure: commentary. 7th ed. Prague: C.H. Beck; 2006. (In Czech.)

18. Kožíšek F. Why is the Czech water industry in crisis? Vodní hospodářství. 2016;66(2):4- 8. (In Czech.)

19. Ford TE. Microbiological safety of drinking water: United States and global perspectives. Environ Health Perspect. 1999 Feb;107 Suppl 1:191206

20. Doležal J, Mareček J, Sedláčková V, Sklenář T, Tunka M, Vobrátilová Z. New building act and related regulations with notes. Prague: Linde; 2006. (In Czech.)

21. Sustek P. Compulsory vaccination from the private law perspective: is anyone obliged to compensate potential personal injury? Jurisprudence. 2017;(3):3-16. (In Czech.)

Received March 8, 2017 Accepted in revised form February 8, 2019 